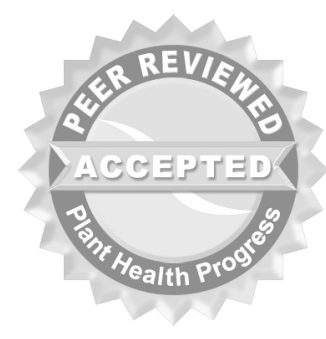

(C) 2013 Plant Management Network.

Accepted for publication 1 February 2013. Published 18 April 2013.

\title{
First Report of Tomato Wilt Caused by Ralstonia solanacearum Biovar 1 in Puerto Rico
}

\author{
Gabriela C. Romero and Consuelo Estévez de Jensen, Crops and \\ Agro-Environmental Sciences, University of Puerto Rico, Mayagüez, \\ PR 00680; and Aaron J. Palmateer, Tropical Research \& Education \\ Center, University of Florida, Homestead, FL 33031 \\ Corresponding author: Gabriela C. Romero. gabriela.romero1@upr.edu
}

Romero, G. C., Estévez de Jensen, C., and Palmateer, A. J. 2013. First report of tomato wilt caused by Ralstonia solanacearum biovar 1 in Puerto Rico. Online. Plant Health Progress doi:10.1094/PHP-2013-0418-01-BR.

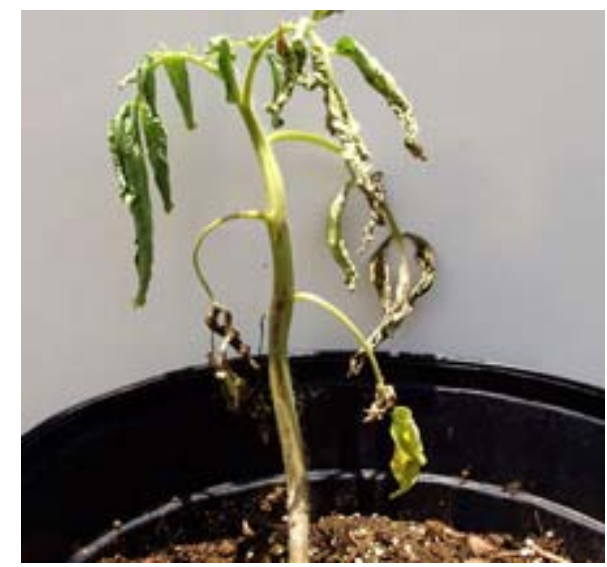

Fig. 1. Bacterial wilt symptoms in tomato inoculated with Ralstonia solanacearum, biovar 1 .
In 2010 bacterial wilt was detected in tomato (Solanum lycopersicum Mill) at a commercial farm in Coamo. Wilting of the foliage was observed in approximately 3,000 plants grown in a steep field. Bacterial streaming from the stem and an immunodiagnostic assay (BID-Rs ImmunoStrip Test, Agdia Inc., Elkhart, IN) conducted in situ indicated that the disease was caused by Ralstonia solanaceraum. Similar symptoms were observed on tomatoes from two different farms in Aguada and Lares, showing breakdown of vascular tissue, necrosis of the buds and wilt. Ralstonia solanacearum was consistently isolated from the three locations on tetrazolium chloride

medium (TZC) (4), after $48 \mathrm{~h}$ at $28^{\circ} \mathrm{C}$. Gram negative bacterial colonies from isolates 1287 from Aguada and 1290 from Lares were white with pink centers and did not grow at $40^{\circ} \mathrm{C}$. Conventional and high-fidelity PCR using primers $759 / 760$ (1) amplified a DNA fragment of 280 bp corresponding to $R$. solanacearum. The sequencing results showed 100\% homology with Ralstonia solanacearum. The sequences of isolates 1287-9 (Gen Bank Accession number JQ771188), 1287-6 (Gen Bank Accession number JQ771190) and 1290-2 (Gen Bank Accession number JQ771189) correspond to an upstream region genomic sequence of Ralstonia solanacearum. Isolates were identified as biovar 1 by the production of acid from trehalose and dextrose and reduction of nitrite from nitrate without gas production. They did not produce acid from maltose, cellobiose, dulcitol, sorbitol, and mannitol. To prove Koch's postulates, forty 'Beefsteak' tomato seedlings (Laurel Seeds Company, San Juan, Puerto Rico) were grown in a commercial substrate (PROMIX). Tomato plants were inoculated with isolates $1287-9$ and 1290-2 with $1 \mathrm{ml}$ of a suspension (10-8 $\mathrm{CFU} / \mathrm{ml}$ of isolates $1287-9$ and 1290-2) by injecting the base of the stem. A negative control with sterile water was included. Plants were kept in a screen house at $23-31^{\circ} \mathrm{C}$ during May and June of 2011. Seven days after inoculation tomato plants developed flaccid leaves and wilted (Fig. 1). Disease severity was rated using the scale 1 to 4: 1 = healthy; 2 = wilting of lower leaves, stem necrosis and brown necrotic lesions; 3 = yellowing and wilting of leaves, exudate, and stem constriction or strangulation; and $4=$ dead plant and production of bacterial exudate (2). Ralstonia solanacearum was reisolated from the stems of the symptomatic plants. Identity of the reisolated bacteria was verified with ELISA and PCR from bacterial colonies and plant tissue. There is not a 
documented report of this disease in Puerto Rico, but an isolate from tomato is cited in a research paper using different strains of Ralstonia solanacearum (3). This is the first report of Ralstonia solanacearum biovar 1 affecting tomato in Puerto Rico. Early identification is essential to prevent its spread to other solanaceous species.

\section{Literature Cited}

1. Fegan, M., Taghavi, M., Sly, L. I., and Hayward, A. C. 1998. Phylogeny, diversity and molecular diagnostics of Ralstonia solanacearum. Pages 19-33 in: Bacterial Wilt Disease: Molecular and Ecological Aspects. P. Prior, C. Allen, and J. Elphinstone, eds. INRA Editions, Paris, France.

2. Gómez, E. A., Álvarez, E., and Llano, G. 2005. Identificación y caracterización de cepas de Ralstonia solanacearum Raza 2, Agente causal del moko del plátano en Colombia. Fitopatol. Colomb. 28:1-8.

3. Poussier, S., Vandewalle, P., and Luisett, I. J. 1999. Genetic Diversity of African and worldwide strains of Ralstonia solanacearum as determined by PCR-restriction fragment length polymorphism analysis of the hrp gene region. Appl. Environ. Microbiol. 65:2184-2194.

4. Schaad, N. W., Jones, J. B., and Chun, W. 2001. Gram-negative bacteria: Ralstonia. Pages 151-166 in: Laboratory Guide for Identification of Plant Pathogenic Bacteria, 3rd Edn. American Phytopathological Society, St. Paul, MN. 